\title{
Mission Impossible? Exploring the Limits of Managing Large IT Projects and Ways to Cross the Line
}

\author{
Robert Winter \\ University of St. Gallen \\ robert.winter@unisg.ch
}

\author{
Peter Rohner \\ University of St. Gallen \\ peter.rohner@unisg.ch
}

\author{
Caroline Kiselev \\ University of St. Gallen \\ caroline.kiselev@unisg.ch
}

\begin{abstract}
For decades much effort has been made to improve project management capabilities. Still, the failure rate remains high, especially for large IT projects. Our postmortem analysis of 15 large IT projects of the Swiss Federal Administration, with an accumulated loss of one billion U.S. dollars, shows that while project management deficits account for some of the failures, project failure is primarily caused by poor project governance capabilities. Based on insights gained from the initial failure analysis, the Swiss Federal Government decided to assess all its large IT projects based on our co-designed framework. Meanwhile, also private companies have assessed IT projects applying our framework. As a consequence, valuable discussions and measures have been initiated and sporadically projects were stopped. The data gained by these assessments will allow to identify patterns that promise to be a reference for governance actors and bodies what information to ask for, when to intervene, and how.
\end{abstract}

\section{Introduction}

Even after many decades of increasingly mature project management practice $1,71 \%$ of IT projects fail completely or partially [1]. In particular, large governmental IT projects (more than 6 million U.S. dollars labor cost) are affected, where the share of complete or partial failure reaches $87 \%$ [2]. Public sector IT projects are six times more likely to overrun costs and twenty times more likely to overrun schedule than similar projects in the private sector [3]. In light of the increasing number of IT projects in the context of digitization in both sectors, it is to be expected that failure costs of IT projects are going to increase even more.

Albeit years of broad attention to IT project success in both IT and project management academia and practice, there remain uncertainty, conflicts and a thirst for knowledge about project success and failure factors. One way towards increasing project success in the future is understanding project failures through retrospective analyses. Such analyses not only help to identify the mistakes made, but also prevent future missteps [4].

For this reason it came as no surprise as four years ago public pressure and disclosure urged the investigation of failed IT projects within the Swiss Federal Administration, which caused a loss amount of ca. one billion U.S. dollars. This need for an indepth postmortem analysis has led to our opportunity to not only co-design an analysis framework, but also to apply it to 15 large, complex, failed IT projects within the Swiss Federal Offices.

The somewhat paradox situation of continuously maturing project management techniques and capabilities, accompanied by the prevailing project failures, triggered the expansion of our focus beyond project management, leading to our research question: "Why do IT projects fail even if project management was carried out according to the state-ofthe-art?"

\section{Background}

To underpin the elements of our analysis framework, we briefly summarize our understanding of both project success and project failure, and define project governance. These concepts are concerned with not only the conformity of project management with the interest of the owner and organization [5, $6]$, but also with the performance of the project (management) within the organization $[7,8]$.

\subsection{Understanding Project Success and Project Failure}

For decades there has been an extensive discussion on how to define project success (and failure)

\footnotetext{
${ }^{1}$ There is a high number of professional project management education programs accompanied by a high demand for practitioners with project management certifications [36]
} 
and its causes. Many publications use the tripartite definition of success - on time, within a set budget, and a requested functionality - often referred to as the iron triangle. However, the concept of the iron triangle has been challenged $[9,10]$ and a broad agreement on how to define project success has not yet been reached. Baccarini [11] split the concept of project success into a process and a product component. Process success is oriented at the iron triangle criteria where "[...] failure is seldom a result of chance. Instead it is rooted in one, or a series of misstep(s) by project managers" [12, p. 70]. Product success, on the other hand, measures the project outcome in terms of user satisfaction and / or realized user benefit. Hence, even if project management has been successful, the final outcome of the project may not fulfil essential stakeholder requirements. As a consequence, it is often suggested to add a benefit component to the concept of the iron triangle or even to shift the emphasis from process to product performance: Project goals should shift from successful deployment (i.e. doing solution development right) to benefit realization in use (i.e. developing the right solutions) $[10,13]$. Considering the context (i.e. social, organizational, political, and technological environments or conditions) becomes essential to delivering a successful project. The context has been identified as critical not only for IT projects, but also for other types of projects $[14,15,16,17]$. In conclusion, we understand a successful project as not only being on time, within a set budget, and meeting requested functionality through a successful project management process, but also as creating an outcome / product that is being used within a given context. Therefore, we argue that the key to project success often lies beyond project management.

\subsection{Doing Things Right vs. Doing the Right Things}

Massive organizational investments, but also increasingly mature methods and certifications have led to a large and highly skilled workforce and pool of experts in the field of project management, which clearly helped to scale up the amount of successfully completed projects. Method support ranges from generic project management methods to those that are specific to agile development (e.g., PRINCE2 Agile [18]), to large IT projects (e.g., HERMES [19]), or even very large infrastructure projects (e.g., S-O-S Method [20]). What all of these project management

\footnotetext{
${ }^{2}$ As HERMES is the reference project management method in our analysis. There are some details given here: HERMES is a project management method for IT projects, which has been expanded to guiding service and product development, and business adjustment projects. The method was developed by the Swiss Federal Administration and is available as an open standard. Be-
}

methods have in common is their focus on doing things right. Project management is understood as "[...] the application of knowledge, skills, tools, and techniques to project activities to meet project requirements" [21, p. 15] by project managers. However, as mentioned before, project success does not solely lie in the hands of the project manager and her team, because projects are embedded not only in an organizational, but also in a specific context (e.g., organizational, technical, political). Hence, if certain conditions are given - no matter all efforts taken for bringing project management to perfection - projects are doomed to failure. The actions of project management depend on decisions made on the project governance level: doing the right thing lays the foundation for doing things right.

Project governance only recently started to gain increasing attention in academia and practice. It is concerned with the alignment of project objectives with the organizational context and strategy [21] and constitutes the framework for project decisions [22]. Actors and bodies on the project governance level are the project sponsor and a steering committee (of which the project sponsor is a member) who set the framework and boundaries for project management (i.e. through definition of policies, processes and roles) and at the same time support project managers in managing the project successfully - i.e. meeting a project's objective [23, 24]. Figure 1 shows project governance and management in hierarchical structure as it is understood in HERMES ${ }^{2}$ [19]:

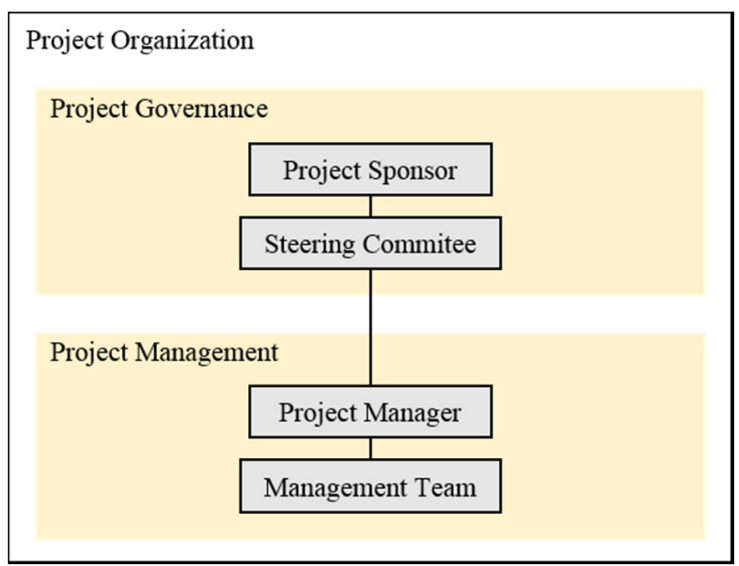

Figure 1. Project organization

Linking the business organization's management and governance level with the project organization, project sponsors have a critical role regarding the performance of large, complex projects $[8,25]$. The

sides the federal administration, which is obligated to use HERMES to manage its IT projects, many other public sector organizations and administrations, as well private sector companies have successfully work with HERMES. There are also HERMES educational courses and certifications. To find more information please go to: https://www.isb.admin.ch/isb/en/home/themen/projektmanagement/hermes.html 
project sponsor and the steering committee represent the business organization with its strategy, vision and goals in the project, allocate resources, and first and foremost are responsible that the right things are done. Doing the right thing can also mean cancelling a project. For example, if there are changes in the business environment that have an influence on requirements and scope, cancelling even an on-track project that however sooner or later will be impacted, might actually be the best decision [26]. Once started, complex projects - like most IT projects - are difficult to control and "the tendency to cover up and deny early indications of project troubles compounds the problems and delays their resolution" [27, p. 69]. In the worst case - when poor contextual conditions are denied - it is almost impossible to prevent a project from failing [28].

An increasing yet small number of organizations and governmental institutions have introduced governance frameworks. Despite the relevance of project governance for project success, there is a lack of research on the roles and processes of project governance [29]. Furthermore, not many practical governance guidelines and methods exist for projects and those are rarely applied or certified [30] [31]. Whereas in most organizations project managers have to bring along the required skills and corresponding certificates for managing a project, project sponsors or steering board members often just slip into their role because of their (hierarchical) position in the organization or their management experience [32]. The high maturity of project management, together with the comparatively low maturity of project governance, constitute the backdrop for the failure analysis presented in the next section.

\section{Failure Analysis through a Co-De- signed Framework}

Public pressure and disclosure has formed our opportunity to analyze 15 large, complex failed IT projects of the Swiss Federal Administration. The study was commissioned to answer the question why, despite the application of a state-of-the art project management method, these projects failed and created losses of together approximately one billion U.S. dollars in a period of less than 10 years - quite a significant amount for a country with only around 8 million inhabitants. As it should be a key objective of every postmortem analysis to investigate not only what went wrong and what went right, but also "[...] make recommendations that might help future project managers avoid ending up in a similar position"

\footnotetext{
${ }^{3}$ The Swiss Parliament consists of two chambers: Swiss National Council and in the Swiss Council of States.
}

[12, p. 70], we focused on discovering failure patterns to derive specific, employable measures to limit the damage of current, shaky projects and ensure the success of future endeavors. In line with Nelson's [4] emphasis on retrospectives as not being limited to the post-implementation phase of a project, another objective was to design an analysis instrument that is also applicable and useful for assessing ongoing projects, hoping that failures can be prevented, present practices improved or changed, and future losses avoided. Thus, our instrument was co-designed with public administration offices that have an interest in applying such an instrument not only for postmortem analysis, but also in ex ante evaluation or project controlling.

\subsection{Studied Projects}

The 15 studied projects are all large and complex governmental IT projects that have been declared as failed by the Federal Chief Information Officer (CIO) - not meeting budget, functionality and / or time targets, and / or not generating promised value to the stakeholders. The projects were conducted in different federal departments and therefore embedded in different environments.

Due to the gravity of failure and public relevance, some of the cases were subject to debate in the Swiss Parliament ${ }^{3}$ as well as to reports of federal Investigation Commissions and even entailed legal lawsuits. Thus, many of the cases have gained broad media and public attention. The encountered damage consisted not only of financial losses, but also non-monetary losses like discontentment and loss of confidence from the general public and the parliament towards federal offices' performance as every financial loss is squandered taxpayer's money after all. All projects had different backgrounds and settings due to their various origins and they all took quite different courses. However, they had in common that project management was based on HERMES [19], the project management method prescribed for all projects of this size. Some projects applied agile procedures, but only for software development purposes. The smallest project in our analysis caused costs of about one million U.S. dollars and the largest around 750 million U.S. dollars (average approx. 85 million U.S. dollars, median approx. 11 million U.S. dollars). In the following, four exemplary projects from our sample are characterized.

\section{Project $A$}

This project was initiated by the Swiss Federal Tax Administration 2001 with the aim to unify and 
replace the existing separately run financial services tax and general value added tax (VAT) information systems by a unified single system focusing on customer processes. Troubles in procurement and disputes between the administration office and the supplier culminated in a cancellation of the contract in 2006 , followed by a disassembly of the original project into many smaller projects with different spon- years. In the end costs ran up to 19 million U.S. dollars and were largely covered by the running budget of the accountable administration office. There were also preliminary investments of around 3 million U.S. dollars. Due to fundamental changes regarding e-government services, the main purpose of the project became widely redundant. However, the project was terminated only upon political interpellations.

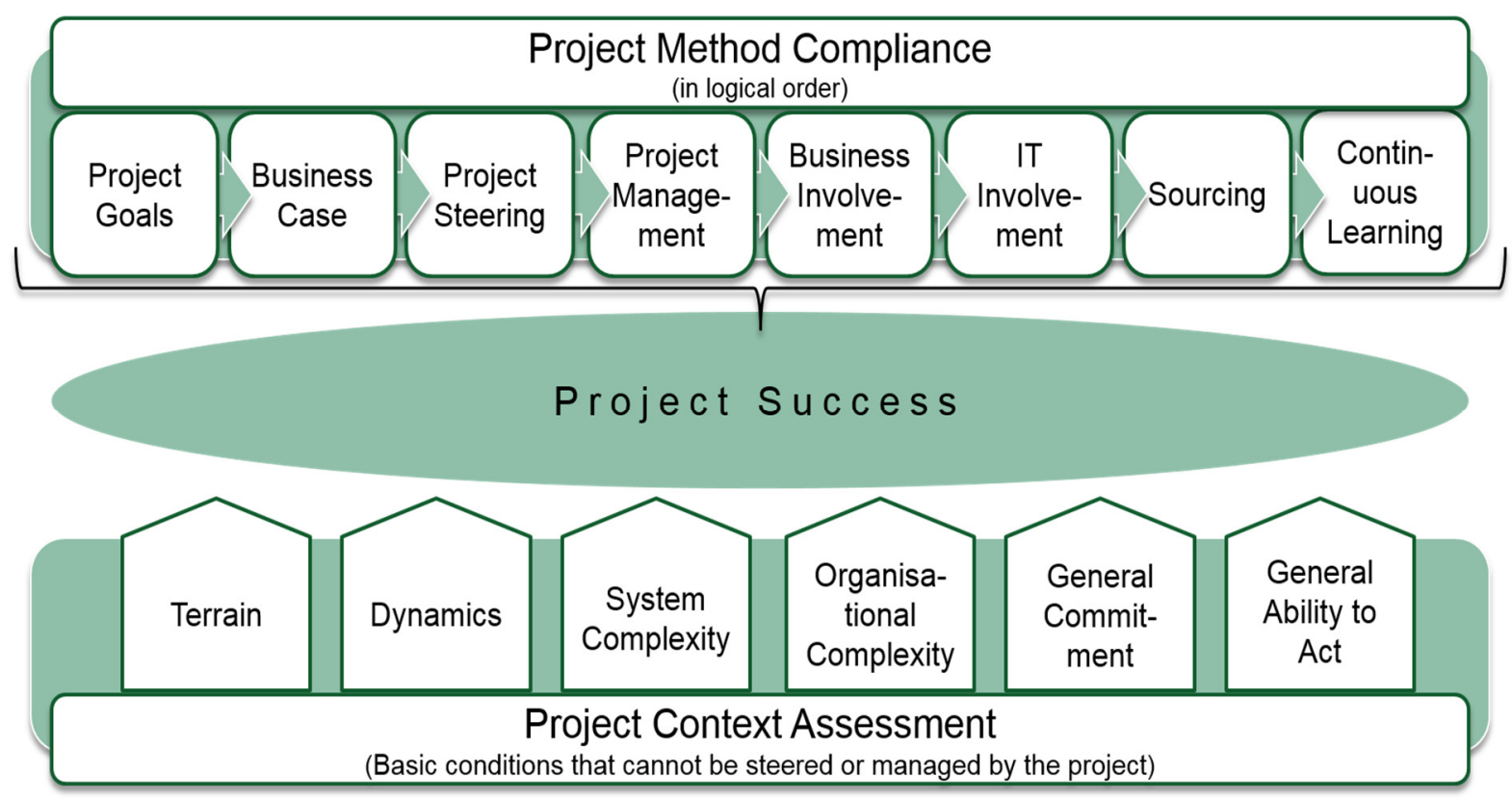

Figure 2. Project analysis model

sors. In subsequent years the projects had gotten out of hand financially so that the entire project bundle was cancelled in 2012. Until that time more than 120 million U.S. dollars had been lost. One year later a follow-up project was launched.

\section{Project $B$}

In 2004 the Swiss Federal Roads Office launched an IT project to build a central data management system to enable administrative bodies from federal to municipal level to manage all road and traffic data more efficiently and effectively. Because of lacking transparency within procurement processes, the violation of the Federal Budget Act, and changing responsibilities of the Swiss Federal Street Administration due to the passing of a new legislation that changed the requirements during the project, costs more than double of the initially budgeted 46 million U.S. dollars had accumulated when the project was stopped.

\section{Project C}

The aim of this project was the development of an e-government, e-voting and tracking solution, designed for the special needs of a federal political system. The original budget at the project launch in 2003 was 1.3 million U.S. dollars per year over four

\section{Project D}

This Project was initiated by the Federal Office of Information Technology, Systems and Telecommunication of the Federal Department of Finance and targeted at the introduction of an electronic standard workspace for all employees of the federal administration. The original budget was 85 million U.S. dollars over 5 years. After planned costs rose up to more than 225 million U.S. dollars the project was suspended. In the end, the project boasted effective costs of 177 million U.S. dollars and a duration of 6 years.

\subsection{Co-Designing an Analysis Framework}

The co-design of our analysis framework was an iterative process: Our first aim was to understand the 15 study projects. Thus, we started with the examination of the 15 projects through an analysis of project documents. We had access to unlimited and extensive documentation, such as project proposals, project plans, phase reports, controlling reports, documents expressing internal and external expertise, protocols of steering committee and project management meetings, project evaluations, and final reports. In order to further deepen our insights we conducted interviews with exponents of the largest projects under investigation. As we understood that due 
to the (still) ongoing debate, which is far from culminating into clearly defined concepts, we might not come to a to-the-point analysis framework by ourselves we started to work with focus groups ${ }^{4}$. We ran focus groups consisting of eleven highly experienced practitioners with several years of leadership and management experience in large, complex projects within the federal administration ${ }^{5}$.

The main outcomes of the co-design phase are an analysis model, two structured questionnaires, a project classification, and a set of failure patterns.

Our project analysis model consists of two dimensions: Project Method Compliance and Project Context Assessment (see Figure 2) ${ }^{6}$.

For each dimension we developed a structured questionnaire that covers 37 and 22 items, respectively ${ }^{7}$. The items are assessed using individual qualitative scales (0-5) - e.g. in terms of project goals the scale ranges from "no formally defined project goals (in written form) that are clear to the involved persons" (0) to "formally defined project goals (in written form) that are mutually derived as well as thoroughly understood and explicitly accepted by every involved person" (6). The single scores of the single items of both the project management compliance analysis and project context assessment are consolidated into an overall score for each management topic resp. context area and finally into an overall score for each studied project.

\section{Dimension 1: Project Method Compliance}

Our initial focus was on examining whether things had been done right. Thus, the goal was to assess the project method compliance of each project in accordance with HERMES project management method as a reference (see Table 1). The single items represent capabilities and activities within a project that can be influenced by the project organization. Each of the eight jointly defined topics consists of several items that are closely related.

Table 1. Project method compliance

\begin{tabular}{|l|l|}
\hline Topic & Items \\
\hline Project Goals & $\begin{array}{l}\text { Intention of sponsor; Goals per sub- } \\
\text { project, Management support for the } \\
\text { project; Expectation management; } \\
\text { Strategic conformity of the project }\end{array}$ \\
\hline Business Case & $\begin{array}{l}\text { Proven value (impact of the solu- } \\
\text { tion); Position of project in portfolio; } \\
\text { Selection of project collaborators }\end{array}$ \\
\hline
\end{tabular}

\footnotetext{
${ }^{4}$ The use of focus groups is a suitable technique for "looking for the range of ideas [...] that people have about something", for "trying to understand differences in perspectives", for getting "ideas to emerge from the group" and for looking for information and opinion in order to design a research study [34, p. 19, 35].

${ }^{5}$ Please see Appendix for more details about the co-designing of the analysis framework.
}

\begin{tabular}{|l|l|}
\hline $\begin{array}{l}\text { Project Steer- } \\
\text { ing }\end{array}$ & $\begin{array}{l}\text { Personnel composition; Responsibil- } \\
\text { ity and accountability (duties and } \\
\text { rules); Monitoring and preventive } \\
\text { measures; Approval of phase transi- } \\
\text { tion }\end{array}$ \\
\hline $\begin{array}{l}\text { Project Man- } \\
\text { agement }\end{array}$ & $\begin{array}{l}\text { Project brief; Project planning and } \\
\text { management; Change management; } \\
\text { Risk handling; Resource Manage- } \\
\text { ment; Solution implementation; } \\
\text { Project controlling; Reserves }\end{array}$ \\
\hline $\begin{array}{l}\text { Business In- } \\
\text { volvement }\end{array}$ & $\begin{array}{l}\text { Process management; Organiza- } \\
\text { tional change management; Fund- } \\
\text { ing; Investment controlling; Enter- } \\
\text { prise architecture; Data management }\end{array}$ \\
\hline $\begin{array}{l}\text { IT Involve- } \\
\text { ment }\end{array}$ & $\begin{array}{l}\text { Solution architecture; mastering } \\
\text { technology; Availability of IT per- } \\
\text { sonnel; Operations and support }\end{array}$ \\
\hline Sourcing & $\begin{array}{l}\text { Fundamental decision making; Re- } \\
\text { quirements management; Procure- } \\
\text { ment processes }\end{array}$ \\
\hline $\begin{array}{l}\text { Continuous } \\
\text { Learning }\end{array}$ & $\begin{array}{l}\text { Experience transfer ex ante/post; } \\
\text { Documentation of experience }\end{array}$ \\
\hline
\end{tabular}

Table 2. Project context assessment

\begin{tabular}{|l|l|}
\hline Area & Items \\
\hline Terrain & $\begin{array}{l}\text { Experience with similar projects and } \\
\text { solutions; Experience with infra- } \\
\text { structure, technology and manage- } \\
\text { ment; Cultural terrain }\end{array}$ \\
\hline Dynamics & $\begin{array}{l}\text { Technological progress; Organiza- } \\
\text { tional changes; Openness to change; } \\
\text { Requirements to be met by the solu- } \\
\text { tion; Political environment; Legal } \\
\text { framework }\end{array}$ \\
\hline $\begin{array}{l}\text { System Com- } \\
\text { plexity }\end{array}$ & $\begin{array}{l}\text { Peripheral technical systems to be } \\
\text { taken into account }\end{array}$ \\
\hline $\begin{array}{l}\text { Organiza- } \\
\text { tional Com- } \\
\text { plexity }\end{array}$ & $\begin{array}{l}\text { Heterogeneity of stakeholders; Com- } \\
\text { plexity of organization }\end{array}$ \\
\hline $\begin{array}{l}\text { General Com- } \\
\text { mitment }\end{array}$ & $\begin{array}{l}\text { Managerial commitment or attitude } \\
\text { towards collaboration of business } \\
\text { organization and project organiza- } \\
\text { tion; Coordination of budget and } \\
\text { project situation }\end{array}$ \\
\hline $\begin{array}{l}\text { General Abil- } \\
\text { ity to Act }\end{array}$ & $\begin{array}{l}\text { Decision-making autonomy within a } \\
\text { project; assertiveness of project or- } \\
\text { ganization towards line organiza- } \\
\text { tion; project capabilities in business } \\
\text { organization }\end{array}$ \\
\hline
\end{tabular}

\section{Results of the Failure Analysis}

During our analysis, we found that some of the projects have obviously failed due to the lack of appropriate project management. However, we also

\footnotetext{
${ }^{6}$ Further explanations on the results in each dimension will follow in the next section ("Results of the Failure Analysis")

7 The questionnaires (questions only) can be found here: https://begsolutions.com/BQMBEG/Downloadwithlink.aspx?DocumentLinkID=280795a1-c1b3-466f-b22df33bd6181fa0
} 
found projects with professional and skilled project teams and state-of-the-art project management that nevertheless ran into massive difficulties and failed.

We created three groups of projects according to their project method compliance: good, medium and weak (see Figure 3 - respective sets of projects / columns are colored green, yellow, and red).

For projects P6, P14, P5, P1 and P9 a weak project management was the major cause for project failure, which comes without surprise. For projects P8, P12, P3, P11, P10 and P4 we assessed some aspects of project management to be appropriate. However, the score for the project method compliance was overall medium. Projects P13, P7, P15 and
P2 were found having flawless project management, while still failing, which comes as a surprise.

Four out of fifteen analyzed projects scored well regarding project management compliance. The reason these projects nevertheless failed is to be found beyond the sphere of influence and power of the project organization. Rather, the failure is caused by the project's context. Our project context assessment showed that almost all projects had difficulties in regards to general commitment and general ability to act (see Figure 4).

Projects

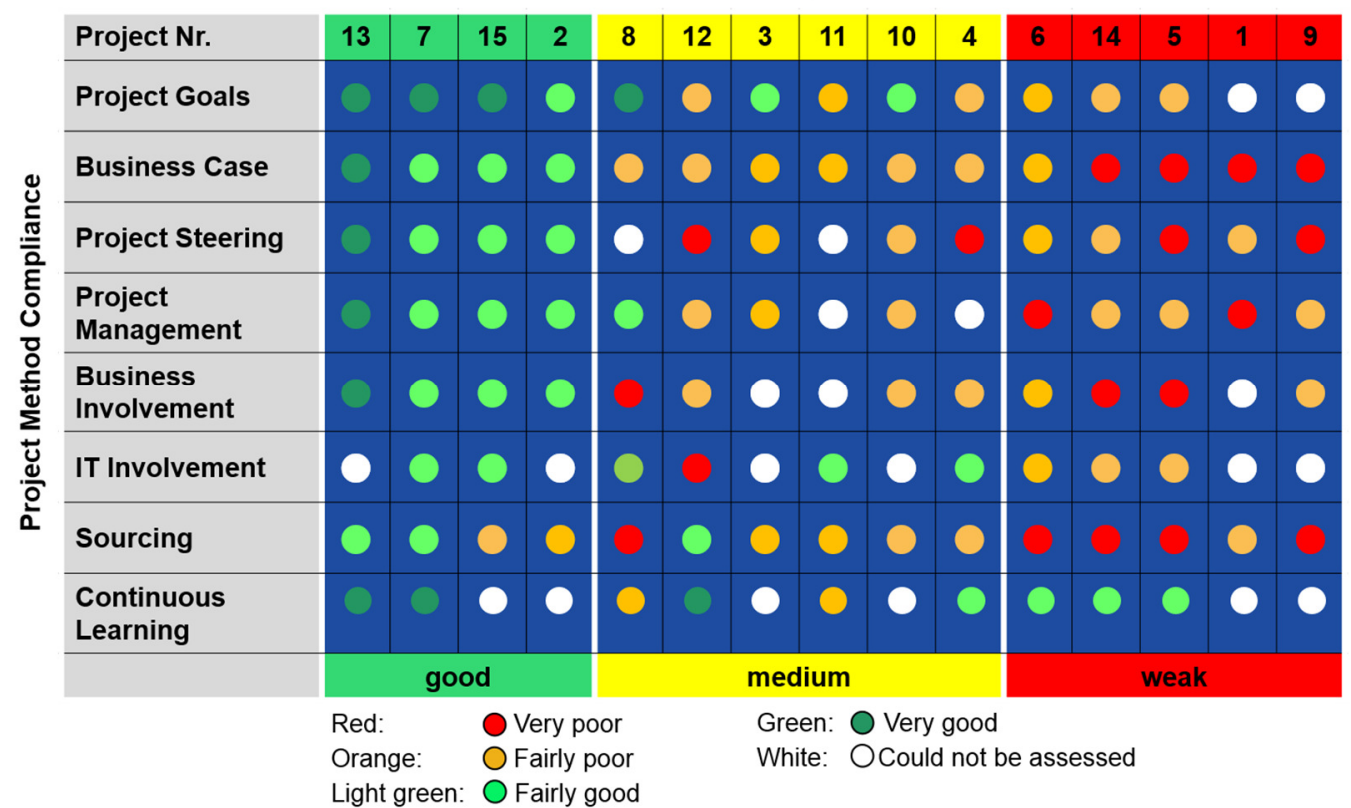

Figure 3. Project Method Compliance Score

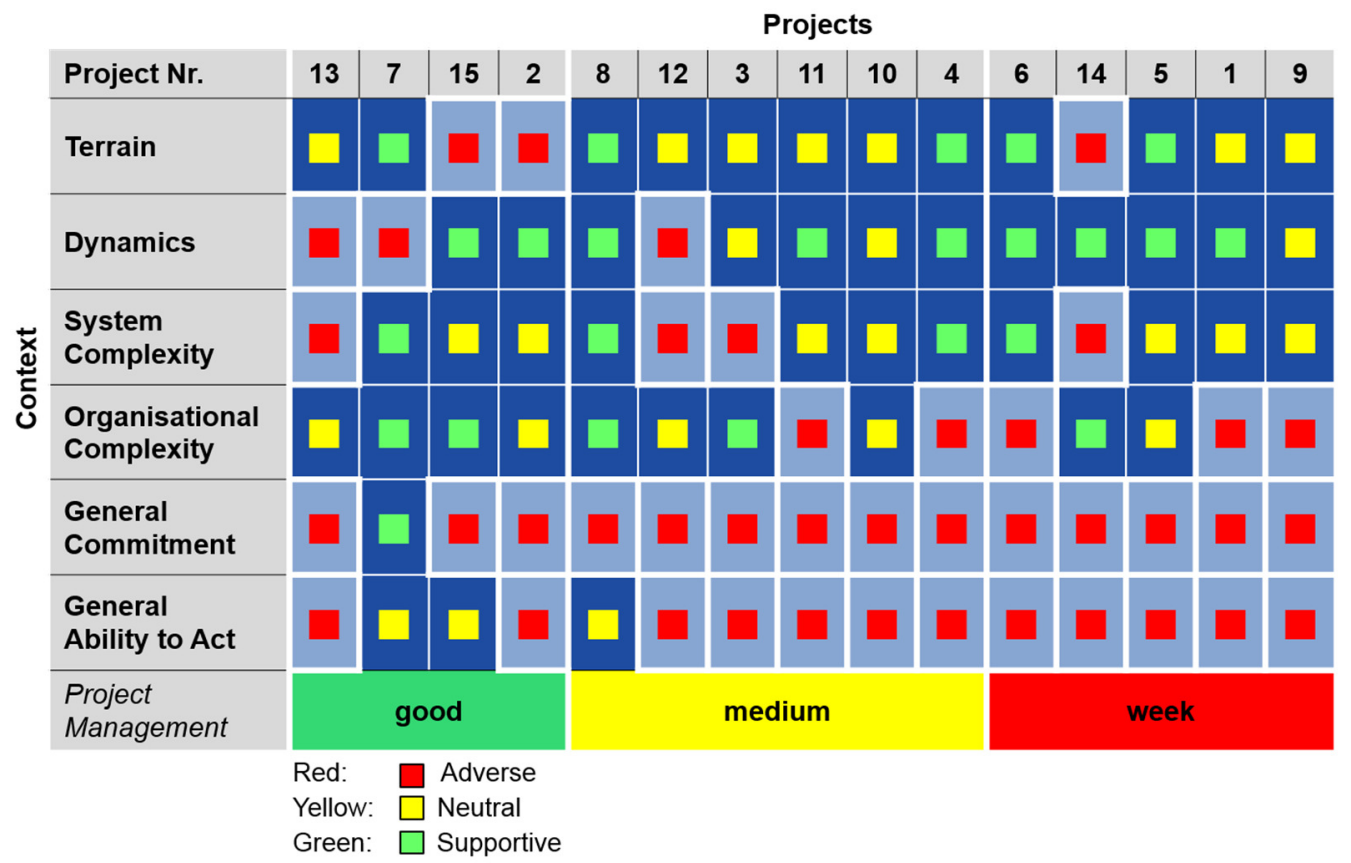

Figure 4. Project Context Assessment Score 
In many cases project managers and sometimes even other organizational actors were aware that the project was not progressing in a satisfactory way. However, they did not have the necessary means or power to get their concerns adequately addressed by their steering committees. In addition to that, in some cases the necessary support and / or understanding for the project in the business organization was inadequate.

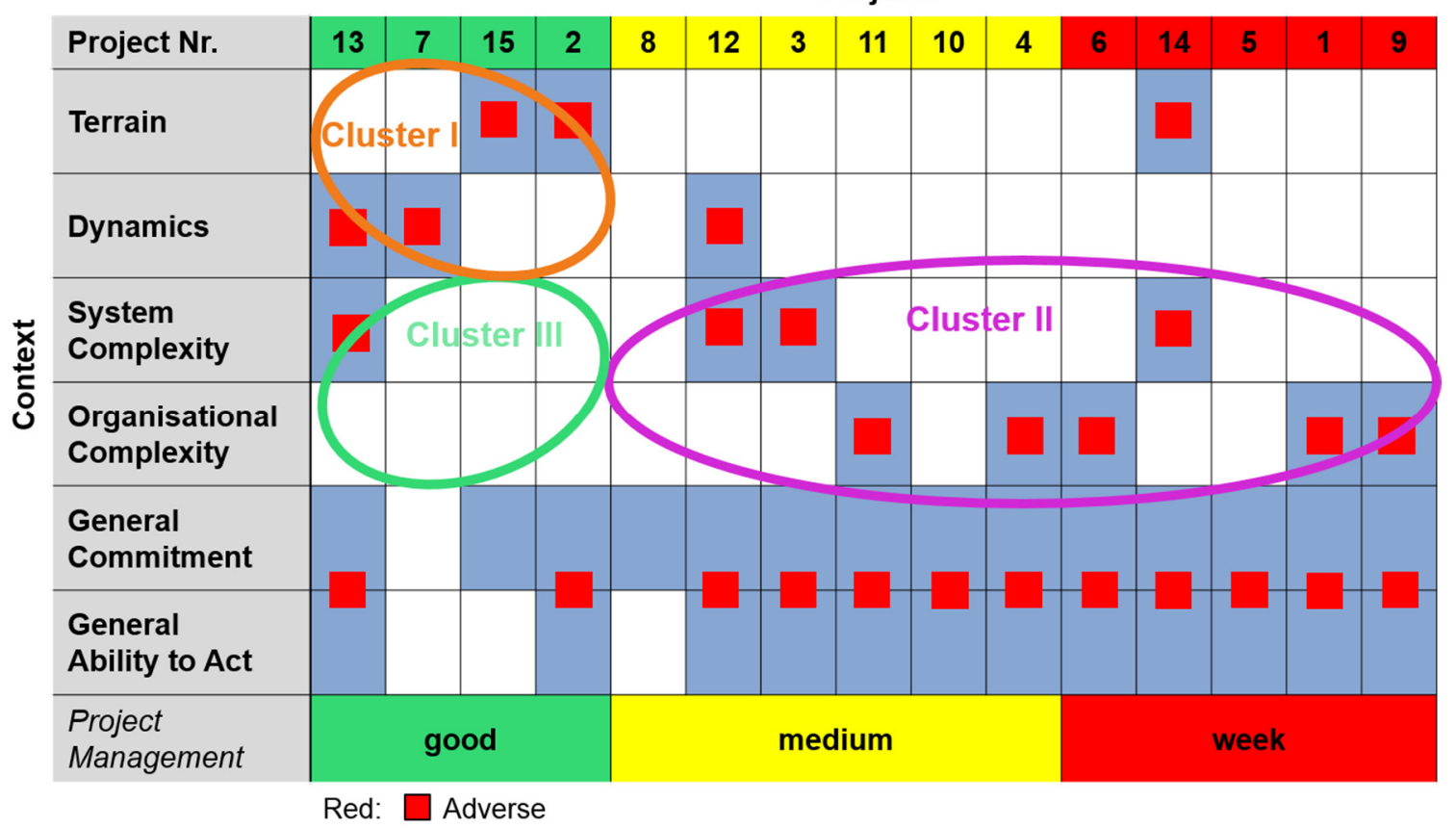

Figure 5. Failure Patterns

The combination of project method compliance scores (dimension 1 of our analysis model) with project context assessment scores (dimension 2 of our analysis model) for each project allowed us to derive patterns that led to the following insights (see figure 5):

Finding \#1 (Cluster I): Even good project management cannot save a mission impossible

All projects that had good scores regarding the project management, but nevertheless failed, faced difficult (pre-)conditions in regard of terrain or dynamics. These difficult (pre-) conditions could obviously not be compensated by good project management alone (i.e. doing things right), particularly in combination with difficult conditions regarding general commitment and general ability to act.

Finding \#2 (Cluster II): Even in known terrain accompanied by low dynamics, complexity endangers the mission if not countered by good project management

Projects that had a medium management score (i.e. had done most things right) or weak management score (i.e. were not adequately managed), even in known terrain and without dynamics challenges failed due to high organizational and / or technological complexity.
Finding \#3 (Cluster III): In known terrain and low dynamics, complexity can be "healed" by good project management

Among the analyzed cases we did not find a single well-managed project that only failed due to difficulties regarding IT complexity and / or organizational complexity. Our third finding is therefore that complexity alone - as long as it is the only contextual challenge - can be compensated by proper project management especially in known terrain and low dynamics.

\section{Proposed Countermeasures}

The analysis phase yielded the conclusion that there is a need for actively taking care of a project's context. As a project's context is beyond the scope of project management, this is a governance task and leadership is necessary in order to understand terrain as well as dynamics and handle complexity so that project missions are defined in a way that gives project management a good chance to succeed. No matter how mature project management is, a project should not be started with a too high amount of tasks in new terrain and / or high dynamics.

Based on our detail analysis, we proposed fourteen measures. All measures were evaluated regarding their relevance and feasibility in a workshop. The 40 participants formally represented all federal 
departments and agencies. The proposed measures were also cross-verified through interviews with exponents of four studied projects. Out of the fourteen proposed measures, twelve were rated as (very or fairly) relevant and (very or fairly) feasible and bundled into three measure packages (see Table 3 ).

These three measure packages are currently "translated" into respective extensions of the HERMES project management method or into supplementary material (like guidelines to steering committees) within the Swiss Federal Administration ${ }^{8}$.

Table 3. Proposed measure packages

\begin{tabular}{|c|c|}
\hline $\begin{array}{l}\text { Measure } \\
\text { Package }\end{array}$ & Measures \\
\hline $\begin{array}{l}\text { "Founda- } \\
\text { tion": } \\
\text { Setting the } \\
\text { foundation of } \\
\text { a successful } \\
\text { project organi- } \\
\text { zation for } \\
\text { large, complex } \\
\text { endeavors }\end{array}$ & $\begin{array}{l}\text { Establishing and upgrading } \\
\text { project management as a rec- } \\
\text { ognized discipline within the } \\
\text { organization; Establishing a } \\
\text { professional project govern- } \\
\text { ance (i.e. project sponsors and } \\
\text { steering committees assuming } \\
\text { their responsibilities); Syn- } \\
\text { chronizing budgeting and } \\
\text { sourcing activities of project } \\
\text { with business organization; } \\
\text { Strengthening sourcing strat- } \\
\text { egy and management }\end{array}$ \\
\hline $\begin{array}{l}\text { "Triage": } \\
\text { Only launch- } \\
\text { ing large, } \\
\text { complex pro- } \\
\text { jects within } \\
\text { good context } \\
\text { and with capa- } \\
\text { ble manage- } \\
\text { ment }\end{array}$ & $\begin{array}{l}\text { Implementing a "filter" (i.e. go } \\
\text { / no go) within a preliminary } \\
\text { phase before a project's ap- } \\
\text { proval focusing on context and } \\
\text { project management method; } \\
\text { Establishing a more structured } \\
\text { and rigorous pre-project phase; } \\
\text { Ensuring consistent monitoring } \\
\text { regarding context and manage- } \\
\text { ment along all project phases }\end{array}$ \\
\hline $\begin{array}{l}\text { "Ability": } \\
\text { Building the } \\
\text { capabilities of } \\
\text { successful, } \\
\text { context-sensi- } \\
\text { tive project } \\
\text { management } \\
\text { and govern- } \\
\text { ance }\end{array}$ & $\begin{array}{l}\text { Building an organization wide } \\
\text { project manager pool; Estab- } \\
\text { lishing communities of prac- } \\
\text { tice to exchange project gov- } \\
\text { ernance and management ex- } \\
\text { perience; Employing internal } \\
\text { and external experts and } \\
\text { coaches to evaluate and sup- } \\
\text { port project managers, spon- } \\
\text { sors, and steering committees; } \\
\text { Emphasizing the building of } \\
\text { effective requirements and } \\
\text { change management capacities }\end{array}$ \\
\hline
\end{tabular}

\footnotetext{
${ }^{8}$ Find more about the integration of the measure packages to HERMES (in German): https://www.newsd.admin.ch/newsd/message/attachments/37501.pdf

${ }^{9} \mathrm{KEY}$ stands for key factors for project success.

${ }_{10}$ This figure comprises of the 15 initial assessments of failed projects within the Swiss Federal Administration, ca. 100 subse-
}

The measure packages can not only be integrated into HERMES or project structures and organizations that use this project management method, they can also be useful to organizations and projects with other plan-driven project methods to trigger discussions and improve their practice.

\section{Contribution to Practice}

Based on our initial study, the Swiss Federal Government decided that all ongoing large IT projects ( $>5$ million U.S. dollars) had to be assessed using our analysis model. In order to facilitate these ca. 100 assessments, we developed a web-based tool $\left(\mathrm{KEY} \mathrm{Tool}^{9}\right)$ and trained assessors. All assessments were done by the respective project teams and moderated by trained assessors. Our assessments are usually organized as workshops (up to 4 hours) attended by the project sponsor, the project manager as well as other relevant project participants (up to 8 people). Guided by the assessors, participants go through a maturity rating (incl. target/actual comparison) of about 59 items regarding project context and project method compliance and have to reach a consensus on each item.

A (small) number of projects were stopped as a consequence of the assessment. For other projects, valuable discussions and measures were triggered by the assessment.

In the meantime the KEY tool has also been deployed to assess large and complex running IT projects within the private sector. The assessment (workshop) has been recognized as a valuable method to find potentials for improvement within a project by all participants. We have been continuously evaluating and refining our tool. It can now be configured (i.e. individual selection of relevant questions, changing of wording of questions, etc.) to ensure an even better match with the project, the applied project method, and user benefit.

The data gained by meanwhile close to $200^{10}$ assessments allows us to continue with the identification of patterns that promise to be a reference for steering committees and project sponsors about what information to ask for, when to intervene, and how to intervene. Furthermore, we are establishing a systematic monitoring of taken measures and their effect on the project's course. For practitioners, insights and patterns may be directly used to challenge actual business practices, including how steering committee members are prepared and supported in their organizations. Moreover, identifying patterns

quent assessments of ongoing projects in the Swiss Federal Administration, and ca. 75 assessments of ongoing projects in the public and private sector. 
can leverage organizational learning regarding large, complex projects and thus contribute to future project success.

\section{Conclusion}

Despite the general lack of consensus about project success and failure causes we were able to co-design an analysis framework through which we initially assessed 15 large, complex IT projects (that have failed) regarding their project management capability (management components) and aspects "beyond project management" (i.e., contextual factors). In order to reduce a project's risk of failure, or rather, ensure its future success, its context has to be understood better, monitored more closely, and changed more effectively. These activities are located on the level of project governance, not of project management. Besides continuously fostering project management excellence, organizations therefore should focus on strengthening their project governance by developing and maintaining stable governance structures, effective processes and ensuring that roles are known and lived correctly. We suggest steering committees and project sponsors to deal with contextual factors (dimension 2 of our analysis model) as rigorously as they are used to deal with management components (dimension 1). Thus, steering committees should establish the analysis of project context as well as the systematic collection and re-use of decision making patterns as standard agenda items. Furthermore, structures and processes that allow an open dialogue between project management and steering level, need to be established to ensure an effective discourse on a project's continuously changing context. Our co-designed framework has allowed public and private organizations to analyze failed or running projects from a holistic perspective and to derive specific governance measures.

\section{References}

[1] The Standish Group, "CHAOS Report 2016.," The Standish Group Interantional Inc., 2016.

[2] T. S. Group, «HAZE,» The Standish Group International Inc, 2015.

[3] McKinsey, «Infrastructure Productivity,» MGI and the McKinsey Infrastructure Practice, 2013.

[4] R. R. Nelson, "Project Retrospectives: Evaluating Project Success, Failure, and Everything In Between," MIS Quarterly Executive, vol. 4, no. 3, pp. 361-372, 2005.

[5] J. Tirole, "Corporate Governance," Econometrica, vol. 69, no. 1, pp. 1-35, 2001.

[6] P. Morris and J. Geraldi, "Managing the Institutional Context of Projects," Project Management Journal, vol. 42, pp. 20-32, 2011.
[7] L. Crawford, T. Cooke-Davies, B. Hobbs, L. Labuschagne, K. Remington und C. Ping, «Governance and Support in the Sponsoring of Projects and Programms,» Project Management Journal, Bd. 39, Nr. 1, pp. 43-55, 2008.

[8] E. Too and P. Weaver, "The management of project management: A conceptual framework for project governance," Project Management Journal, vol. 32, no. 8, pp. 1382-1394, 2014.

[9] L. Ika, "Project success as a topic in project management journals," Project Management Journal, vol. 40, no. 4, pp. 6-19, 2009.

[10] N. Doherty , C. Ashurst and J. Peppard, "Factors affecting the successful realisation of benefits from system development projects," Journal of Information Technology, vol. 27, no. 1, pp. 1-16, 2012.

[11] D. Baccarini, "The logical framework method for defining project success," Project Management Journal, vol. 30, no. 4, pp. 6-19, 1999.

[12] R. Nelson, "IT Project Management: Infamous Failures, Classic Mistake, and Best Practices," MIS Quarterly Executive, vol. 6, no. 2, pp. 67-78, 2007.

[13] J. Peppard and J. Ward, "Managing the Realization of Benefits from IT Investments," MIS Quarterly Executive, vol. 6, no. 1, pp. 1-11, 2007.

[14] E. Conforto, D. Capaldo Aramal, S. da Silva, A. Di Felippo and D. Kamikawachi, "The agility construct on project management theory," International Journal of Project Management, vol. 34, no. 4, pp. 660-674, 2016.

[15] A. Shenhar, A. Tishler, D. Dvir, S. Lipovetsky and T. Lechler, "Refining the search for project success factors: a multivariate typological approach," $R \& D$ Management, vol. 32, no. 2, pp. 111-126, 2002.

[16] T. Lechler and D. Dvir, "An alternative taxonomy of project management structures: linking project management structures and project success," IEEE Transaction on Engineering Management, vol. 57, no. 2, pp. 198-210, 2010.

[17] S. Wearne, "Evidence-Based Scope for Reducing "Fire Fighting" in Project Management," vol. 45, no. 1, pp. 67-75, 2014.

[18] PRINCE2, "PRINCE2 Agile® Foundation \& Practitioner," 2018. [Online]. Available: https://www.prince2.com/eur/training/prince2agile/foundation-practitioner?t=20180608 . [Accessed May 2018].

[19] HERMES, "HERMES," 2018. [Online]. Available: http://www.hermes.admin.ch/index.xhtml. [Accessed May 2018].

[20] S.-O.-S. Methode, "Konzepte und Inhalte des VModell XT Bund," 2018. [Online]. Available: http://download.gsb.bund.de/BundesCIO/VModell_XT_Bund/V-Modell\%20XT\%20Bund2.0-HTML/6b3c15700023377.html. [Accessed May 2018].

[21] PMI, A guide to the Project Management Body of Knowledge (PMBOK Guide), Project Management Instiute, 2013. 
[22] R. Garland, Project Governance: A Practical Guide to Effective Project Decision Making, Philadelphia, PA: Kogan Page Publishers, 2009.

[23] G. Volden and K. Samset, "Governance of Major Public Investment Projects: Principles and Practices in Six Countries," vol. 48, no. 3, pp. 90-108, 2017.

[24] R. Mueller, "Project Governance," CEPIS UPGRADE, vol. XII, no. 5, December 2011.

[25] R. Miller and B. Hobbs, "Governance regimes for large complex projects," Project Management Journal, vol. 36, no. 3, pp. 42-50, 2005.

[26] K. El Emam and A. Koru, "A replicated survey of IT software project failures," IEEE software, vol. 25, no. 5, pp. 84-90, 2008.

[27] C. Iacovou and A. Dexter, "Turning Around Runaway Information Technology Projects," vol. 46, no. 6, pp. 68-88, 2004.

[28] S. Goldfinch, "Pessimism, computer failure, and information systems development in the public sector," Public Administration Review, vol. 67, no. 5, pp. 917-929, 2007.

[29] K. Murphy, K. Lyytinen and T. Somers, "A SocioTechnical Model for Profect-Based Executive IT Governance," HICSS, pp. 4825-4834, 2018.

[30] P. Dinsmore und L. Rocha, Enterprise Project Governance: A Guide to the Successfull Management of Projects Across the Organization, Chicago: Amacom, 2012.

[31] R. Mueller, L. Zhai, A. Wang and J. Shao, "A framework for governance of projects: Governmentality, governance, structure and projectification," International Journal of Project Management, vol. 34, no. 6, pp. 957-969, 2016.

[32] R. Englund and A. Bucero, Project Sponsorship: Achieving Management Commitment for Project Success, San Francisco: Wiley, 2015.

[33] M. Simard and D. Laberge, "Governance challenges in temporary organizations: a case of evolution and representations," International Journal of Information Systems and Project Management, vol. 2, no. 4, pp. 39-58, 2014.

[34] M. Tremblay, A. Hevner and D. Berndt, "Use of Focus Groups in Design Science Research," in Design Research in Information Systems Theory and Practice, Boston, Springer, 2010, pp. 121-143.

[35] R. A. Krueger and M. A. Casey, Focus groups: A practical guide for applied science research, Thousand Oaks: SAGE, 2014.

[36] PMI, «Project management salary survey,» Newton Square, PA, 2011.

\section{Methodological Appendix}

The goal of the first round of focus group meetings was to narrow down the broad range of success and failure factors and aligning them with the prescribed management method HERMES. The outcome was a generally applicable structured questionnaire with questions, relevant for the analysis of the projects

Before the questionnaire was applied to all study projects, it had been evaluated and finalized in a joint workshop with the Federal CIO Office (prior to the investigation neither the Federal CIO nor members of his office had an active role in any of the analyzed projects). The final structured questionnaire addressed eight different management areas and also contained a form to record general information (characteristics) about the project. The eight areas (i.e. project goal, business case, project steering, project management, business involvement, IT involvement, sourcing and continuous learning) were determined based on the standardized project management method HERMES, which had been applied in every studied project.

After analyzing all cases on the basis of our questionnaire (every item rated between 0-5) we consolidated the results of the items and rated every area in the questionnaire with either positive, rather positive, rather negative or negative.

In a second round of focus group meetings we clustered the cases regarding their context in order to make the project's context comparable and to eventually identifying patterns. We then mutually derived six contextual factors (i.e. terrain, dynamics, system complexity, organizational complexity, general commitment, and general ability to act) distinguishing the context of the projects. Thereafter a structured questionnaire was developed and applied to assess the contextual exposure of all 15 projects. Each contextual area was rated as supportive, neutral or adverse.

In the end all findings were discussed and reevaluated by the focus groups and finally presented to members of the Federal CIO Office, where we found mutual agreement about the results and the applicability of our co-designed framework. 